\title{
OTORITAS AGAMA DI ERA KORONA: DARI FRAGMENTASI KE KONVERGENSI?
}

\author{
Mohammad Zaki Arrobi, Amsa Nadzifah \\ Universitas Gadjah Mada, Komunitas dan Perpustakaan The Peace \\ zaki.arrobi@ugm.ac.id, amsanadzif.ragil@gmail.com
}

\begin{abstract}
Abstrak
Artikel ini berupaya menarasikan pandangan, sikap, dan peran otoritas keagamaan Islam dalam merespons situasi pandemi akibat penyebaran virus korona di Indonesia. Fokus artikel ini adalah artikulasi wacana keagamaan dan praksis sosial yang dilakukan oleh 'ustad selebritis' dan organisasi massa Islam dalam menghadapi pandemi akibat Covid-19.Tulisan ini mengulas pergeseran wacana di kalangan otoritas keagamaan menyangkut isu Covid-19. Di saat wabah korona belum terdeteksi di Indonesia yakni di bulan Januari-Februari, respons otoritas agama mengalami fragmentasi dan kontestasi. Fragmentasi ini ditunjukkan dengan adanya gap antara sikap pro aktif dan konstruktif mayoritas pemuka dan organisasi agama dengan sikap reaktif dan kontra produktif sebagian kecil pemuka agama lainnya. Lambat laun, seiring dengan kasus Covid-19 yang kian menyebar di tanah air, otoritas agama baru berupa 'ustad selebritis' maupun otoritas agama lama seperti MUI, Muhammadiyah, dan NU mengalami konvergensi wacana dan praksis keagamaan dalam merespons Covid-19. Mereka sama-sama bekerja keras meyakinkan umat Islam bahwa pesan otoritas agama selaras dengan panduan otoritas kesehatan.
\end{abstract}

Kata kunci: Korona,Ustad Selebritis, Organisasi Islam, Otoritas Agama, Covid-19

\section{Pendahuluan}

Di tengah pandemi global akibat penyebaran Covid-19, agama memainkan peranan yang signifikan baik sebagai kekuatan positif-konstruktif yang ikut memitigasi wabah maupun sebagai kekuatan reaktif yang turut menyebarkan virus. Sebagai kekuatan positif, agama dalam manifestasinya berupa otoritas agama, institusi agama, hingga tokoh agama berperan dalam melakukan 
pencegahan dengan berbagai cara, mulai dari sosialisasi, edukasi, hingga prevensi penyebaran wabah di tengah-tengah umat beragama. Para pemimpin agama berperan penting sebagai kekuatan konstruktif dengan memfatwakan untuk mengganti ibadah ritual agama secara daring maupun dari rumah masingmasing. Para imam dan ustad meniadakan sholat berjamaah dan sholat Jum'at di masjid dan menggantinya dengan sholat berjamaah di rumah, bahkan ibadah sholat tarawih dan kegiatan selama bulan Ramadhan pun dilakukan dari rumah, umat Kristiani melaksanakan ibadah Jumat Agung dan paskah mereka dari rumah, umat Hindu di Bali meniadakan perayaan hari raya Nyepi demi memperkecil risiko penularan wabah dan masih banyak contoh lain bagaimana agama menjadi kekuatan yang turut memitigasi penyebaran virus mematikan ini.

Di sisi yang lain, agama juga dapat menjadi kekuatan reaktif dan kontraproduktif yang ikut menyebarkan wabah ini melalui ritual-ritual keagamaan yang melibatkan kerumunan massa. Fenomena ini sudah terjadi di berbagai negara. Di Korea Selatan, pusat penularan terbesar terjadi melalui kongregasi umat Kristiani di gereja Shincheonji, separuh dari korban terinfeksi virus korona berasal dari jemaat gereja ini. Sementara di Malaysia, event tahunan Jamaah Tabligh yang dihadiri ribuan orang dari berbagai negara menjadi pusat penyebaran virus ini di Malaysia, bahkan hingga ke Singapura dan Indonesia. Di India, ketegangan penganut agama Hindu dan Islam belakangan ini semakin diperparah dengan propaganda dan hasutan kebencian yang melibatkan isu Covid-19. Termasuk ke dalam 'sisi gelap' agama ini adalah sikap-sikap pengingkaran (denial), meremehkan, bahkan anti-sains yang berkembang di sebagian tokoh-tokoh agama dalam merespons Covid-19.

Di Indonesia, di mana otoritas dan institusi agama masih memainkan peranan yang signifikan di tengah masyarakat yang relijius, otoritas agama secara aktif merespons situasi pandemi Covid-19 melalui berbagai cara. Tulisan ini hendak mendiskusikan bagaimana otoritas agama Islam -melalui institusi dan tokoh agamanya-merespons Covid-19 dalam bentuk wacana dan praktik keagamaan. Otoritas agama dalam Islam dapat didefinisikan sebagai 'titik referensi' (point of reference) dan identitas dalam tradisi keagamaan tertentu yang berkembang sebagai 'pengetahuan' agama, kepercayaan, dan struktur simbolik yang direpresentasikan dalam pengalaman ritual dan komunitas beragama (Azra, Dijk, dan Kaptein, 2010). 
Sebagaimana kehadiran media cetak (print media) di awal abad XX yang mengubah lanskap otoritas keagamaan di Nusantara (Burhanuddin, 2010), kemunculan media baru (new media) sejak dekade 1980an juga mentransformasi wajah otoritas keagamaan di Indonesia. Fragmentasi dan pluralisasi otoritas agama Islam yang dipicu oleh disrupsi teknologi media baru melahirkan apa yang disebut Anderson (2003) sebagai 'penerjemah Islam baru'. Di Indonesia, kelahiran 'penerjemah Islam baru' ini dimungkinkan oleh dua faktor struktural yang saling berkaitan, yakni gelombang liberalisasi ekonomi-politik di saat reformasi 1998 yang secara simultan diiringi dengan revolusi teknologi informasi dan komunikasi di akhir tahun 1990an (Slama, 2018). Di Indonesia, 'penerjemah Islam baru' ini dikaitkan dengan fenomena menjamurnya 'ustadz selebritis' yang dibesarkan oleh media televisi nasional di awal tahun 2000an. Selanjutnya, mereka kemudian dikenal piawai dalam menggunakan teknologi komunikasi-informasi berbasis internet sebagai media dakwahnya.

Dalam konteks ini, artikel ini akan menganalisis bagaimana situasi pandemi Covid-19 direspons oleh dua otoritas agama Islam, yakni otoritas agama baru (new religious authority) yang disimbolkan dalam 'ustad selebriti' (celebrity preacher) seperti Abdullah Gymnastiar, Ustad Abdul Somad, Ustad Adi Hidayat dan otoritas agama lama (old religious authority) sebagaimana direpresentasikan oleh 'ulama tradisional' dan organisasi-organisasi arus utama Islam di Indonesia, seperti Majelis Ulama Indonesia (MUI), Muhammadiyah, dan Nahdlatul Ulama.

Berseberangan dengan temuan studi-studi sebelumnya yang menyebut kehadiran otoritas agama baru akan menggerus pengaruh otoritas agama lama (lihat Muzakki, 2012; Iqbal, 2014; Burhani, 2016, 2018; Akmaliah, 2019; Arifianto, 2019), studi ini menemukan adanya konvergensi otoritas agama dalam merespons situasi pandemi akibat penyebaran Covid-19. Meski sempat terjadi fragmentasi bahkan kontestasi antar otoritas agama, seiring waktu wacana dominan dua otoritas agama Islam ini cenderung mendekat: sama-sama menekankan pentingnya untuk menyelamatkan jiwa manusia dari bahaya Covid-19. Wacana ini diterjemahkan mereka dalam bentuk seruan dan himbauan agar melakukan ibadah ritual di rumah masing-masing, bahkan mengeluarkan fatwa keagamaan dan panduan beribadah di saat pandemi sebagaimana yang dilakukan oleh MUI, Muhammadiyah dan NU. Selain itu, mereka juga menerjemahkan wacana keagamaan mereka ke dalam praksis sosial untuk membantu penanganan Covid-19. 


\section{Beragamadi era Pandemi}

Di Indonesia, pemuka dan organisasi keagamaan memiliki penafsiran yang beragam terkait dengan pageblug korona. Ada yang menanggap bahwa Covid-19 merupakan tentara Allah, namun ada pula yang beranggapan bahwa Covid-19 merupakan 'setan-setan'. Organisasi keagamaan seperti MUI, Muhammadiyah dan NU mengeluarkan panduan ibadah selama terjadi pandemi. Namun, tidak semua masyarakat mematuhinya, beberapa diantaranya memiliki sikap fatalis dengan menganggap bahwa hidup dan mati ada di tangan Tuhan, dan tidak melakukan usaha pencegahan. Bahkan, terkait dengan keputusan untuk sholat jamaah di rumah, beberapa masyarakat beranggapan penutupan tempat ibadah sebagai upaya penghentian Covid-19 adalah bentuk konspirasi iblis, jin, dan setan untuk menjerumuskan manusia (Fathurrahman, 2020). Benar kiranya bahwa kaum beragama menghadapi pilihan sulit di tengah pandemi: memilih 'mengkarantina ibadah' di rumah atau menganggap wabah sebagai 'ujian keimanan' sehingga menolak 'pembatasan sosial' dengan Tuhan? (Hosen, 2020).

Ritual keagamaan juga menjadi sorotan di saat pandemi karena terbukti menjadi salah satu episentrum penyebaran wabah di beberapa negara. Ritual keagamaan yang memobilisasi massa dalam jumlah besar juga menjadi salah satu klaster penyebaran Covid-19 di Indonesia. Salah satunya adalah pertemuan Ijtima Ulama Dunia Zona Asia yang dilaksanakan di Gowa, Sulawesi Selatan. Meski acara ini akhirnya dibatalkan namun acara ini telah berhasil mengumpulkan 8000 orang dari sedikitnya 48 negara, beberapa peserta kemudian dinyatakan positif saat berada di daerah masing-masing (watchdoc documentary, 17/04/2020). Para peserta Ijtima' Ulama ini saat ini sedang 'diburu' untuk didata dan dikarantina oleh pemerintah daerah masing-masing (Tempo, 27/4/2020). Selain kegiatan Ijtima' Ulama, ada ritual keagamaan lainnya yang menjadi klaster penyebaran wabah yakni, Sidang Sinode Gereja Protestan Indonesia bagian Barat (GPIB) di Bogor yang dihadiri 600 orang dari 25 provinsi, empat orang dinyatakan positif dan satu diantaranya meninggal dunia.

Adanya ritual keagamaan sebagai klaster penyebaran Covid-19 menegaskan bahwa agama juga memiliki peran sentral di tengah situasi pandemi. Menurut Haidar Bagir dalam diskusi mengenai 'Agama di Era Corona' yang dilaksanakan oleh PUSAD Paramadina (10/04), tidak ada pertentangan antara agama dan sains. Permasalahan yang terjadi di masyarakat adalah karena kesempitan wawasan agama sehingga perlu pendidikan agama yang lebih terbuka. Menurutnya, pandemi Covid-19 ini merupakan momentum untuk pemuka 
agama dan organisasi agama untuk bersatu dan mengajak jamaah masing-masing untuk memiliki pemikiran yang terbuka dan lebih apresiatif terhadap ilmu pengetahuan. Untuk menuju umat beragama yang berpikiran maju, terbuka serta apresitatif terhadap ilmu pengetahuan, diperlukan otoritas agama yang progresif dan pro-aktif dalam memandu umat dalam menyikapi dan memitigasi situasi pandemi.

Apakah para pemuka dan organisasi agama Islam di Indonesia sudah bersikap pro-aktif dan progresif dalam merespons dan memitigasi situasi pandemi? Ataukah masih terjebak pada sikap fatalistik bahkan anti-Sains? Pertanyaanpertanyaan ini akan dielaborasi di bagian di bawah ini.

\section{Fragmentasi Otoritas Keagamaan dalam Merespons Covid-19}

Wabah korona diyakini bermula dari kota Wuhan, Cina, pada Desember 2019 yang kemudian menyebar ke berbagai negara. Pada awal penyebaran virus ini, pemerintah Indonesia dinilai lamban dalam merespons dan melakukan aksi pencegahan. Otoritas pemerintah juga cenderung meremehkan bahkan bersikap denial terhadap ancaman virus korona yang sudah di ambang mata di bulan Januari-Februari. Misalkan, Menteri Kesehatan, Terawan Agus Putranto, mengatakan tidak perlu takut dengan virus korona karena yakin doa telah membuat Indonesia 'kebal' dari virus korona. Pernyataan pejabat pemerintah yang cenderung meremehkan Covid-19 juga nampak dari statemen Wakil Presiden RI, Ma'ruf Amin (26/02/2020),yang mengatakan bahwa para kyai dan ulama membaca do'a qunut untuk menolak balasehingga korona minggir di Indonesia.

Pandangan fatalis dalam merespons Covid-19 tidak hanya menjadi monopoli pejabat pemerintah saja, namun juga menjadi pandangan beberapa pemuka agama. Pada tanggal 8 Februari, kanal Youtube bernama Ustad Abdul Somad Lovers menggunggah ceramah Abdul Somad Batubara di Malaysia yang berdurasi 53.16 menit yang kemudian menjadi viral karena pernyataan UAS bahwa korona merupakan tentara Allah.

Tapi Allah masih kasihan. 'Aku masih iba melihat kamu,' kata Allah. Maka [ummat] ditolong Allah dengan berbagai macam tentara. Macam-macam tentara Allah datang [untuk menolong ummat]. Ada pula tentara yang terakhir ini bernama korona. Orang yang berada di Uighur, tak terkena virus ini. Banyak orang terheran-heran apa sebab [orang-orang Uighur tidak terkena korona]. 
Pernyataan UAS bahwa korona adalah tentara Allah menuai kritisisme di masyarakat. Salah satu keheranan itu dituliskan oleh Novi Basuki, kandidat doktor di Sun Yat-sen University, menyatakan bahwa faktanya Uighur merupakan nama suku dan bukan nama wilayah di Cina, lokasi di Cina yang menjadi tempat tinggal Muslim seperti Xinjiang dan Xibei juga terdampak oleh Covid-19. Pernyataan UAS dibantah oleh intelektual Muslim terkemuka, Azyumardi Azra. Mantan Rektor UIN Syarif Hidayatullah tersebut menyatakan bahwa Covid-19 tidak memandang agama. Hal ini dikarenakan, warga Wuhan tidak hanya penganut Tao atau ateis-komunis, ada catatan resmi tentang Muslim Cina Hui yang wafat terkena wabah korona.

Meski demikian ada juga pemuka agama yang mendukung pernyataan dari UAS. Pihak yang mendukung pernyataan tersebut datang dari Wakil Ketua MUI, Muhyiddin Junaidi yang mengatakan bahwa pernyataan UAS sah karena kesombongan manusia sehingga mendapatkan teguran dari Allah (tagar.id, 01/04/2020). Bentuk kesombongan ini adalah dengan memakan makanan yang telah diharamkan -banyak pihak meyakini virus korona bermula dari pasar di Wuhan yang menjual binatang liar seperti kelelawar yang dikonsumsi warga- hal ini bertentangan dengan Al Qur'an 2:168.

Pandangan yang berbeda disampaikan oleh Quraish Shihab dalam kanal Youtube Shihab Eु Shihab (Najwa Shihab, 01/04/2020) yang menyatakan ketidaksetujuannya terkait pernyataan bahwa virus korona adalah tentara Allah. Dalam video tersebut, alih-alih menyebut korona sebagai tentara Allah, Shihab mengatakan bahwa virus ini (Covid-19) sebagai setan-setan yang harus diperangi manusia. Sementara itu, Habib Luthfi bin Yahya pada salah satu kajiannya, menghimbau kepada jamaah yang hadir untuk terus bekerja, bersekolah, dan pergi ke pasar. Setelah adanya himbauan pemerintah untuk melakukan social distancing, Habib Luthfi, yang notabene merupakan salah satu anggota Dewan Pertimbangan Presiden (Wantimpres), masih melaksanakan kajian secara tatap muka (20/03) dengan mempertanyakan mengapa mesti takut (dengan korona). Meski Habib Luthfi tetap menegaskan wajib hukumnya untuk melakukan ikhtiar, pernyataan itu dinilai tidak sensitif pada upaya pencegahan wabah.

Sedangkan respons Aa Gym dan UAH seragam dalam menanggapi pandemi Covid-19. Sebelum adanya pengumuman pemerintah untuk melakukan jaga jarak pada 15 Maret 2020, keduanya telah mengumumkan untuk memindahkan setiap kajiannya ke media daring. Melalui video yang diunggah di kanal youtube Aagym Official, Aa Gym mengumumkan bahwa kegiatan belajar mengajar di 
Pesantren Darut Tauhid menjadi belajar daring dari rumah masing-masing siswa, menghentikan kegiatan yang bersifat pengumpulan massa, dan menunda kunjungan dari dan ke Darut Tauhid hingga waktu yang tidak ditentukan. Senada dengan yang dilakukan oleh Aa Gym, UAH juga melakukan himbauan tentang pencegahan dan penanganan virus korona melalui berbagai kanal media sosialnya.

Jika pandangan dan sikap di kalangan 'ustad selebritis' dan ulama cenderung beragam, sikap dan pandangan organisasi Islam arus utama seperti MUI, Muhammadiyah, dan NU cenderung seragam. Hanya saja ketiganya memiliki aksentuasi yang berbeda dalam merespons pandemi korona di Indonesia. Misalkan, Muhammadiyah dengan cekatan melakukan langkah praktis di bidang kesehatan dan ekonomi, sedangkan MUI dan NU cenderung melakukan pendekatan spiritual dengan menganjurkan masyarakat untuk berdoa dan membentuk satuan tugas khusus penanganan Covid-19. Sebagai upaya melawan Covid-19, ketiganya menggunakan media daring yang beragam. NU melalui kanal youtube 'NU Channel'dan 'NU Online' serta akun Instagram 'nuonline_id' secara berkala menyajikan do'a, ngaji, dan taubat bersama secara daring bersama para ustad dan ulama untuk merespons pandemi. Sedangkan MUI lebih aktif menggunakan situs resminya untuk menyampaikan fatwa dan edukasi kepada masyarakat. Sementara itu, Muhammadiyah menggunakan situs covid19.muhammadiyah.id untuk memberikan informasi secara berkala setiap harinya dan memberikan edukasi melalui video dan infografis terkait dengan Covid-19.

Meski berbeda dalam penggunaan media komunikasi dalam merespons Covid-19, ormas-ormas Islam arus utama ini memiliki cara pandang yang relatif seragam dalam menghadapi wabah korona: sama-sama responsif dalam memitigasi pandemi. Sehari setelah Presiden Jokowi mengumumkan kasus pertama Covid-19 di Indonesia (3/03), PBNU mengeluarkan instruksi untuk berdoa tolak bala agar bangsa tehindar dari musibah dan bencana (Sahal, nu.or. id, 04/04/2020). Himbauan yang senada juga dikeluarkan oleh MUI pada taushiyahnya berjudul 'Menangkal dan Menghadapi Penyebaran Virus Korona' yang dikeluarkan pada tanggal 3 Maret 2020. SedangkanPP Muhammadiyah menyiagakan 64 rumah sakit, sekolah, perguruan tinggi, dan jaringan kader dengan membentuk Tim Muhammadiyah Covid-19 Command Center (MCCC) (Arigi, tempo.co, 01/04/2020). 
Penyebaran wabah Covid-19 direspons secara beragam oleh otoritas keagamaan Islam. Di kalangan pemuka agama, ada yang sangat pro-aktif memitigasi risiko penularan wabah namun ada juga yang tetap menyelenggarakan kajian dengan berkerumun bahkan melakukan disinformasi soal korona. Akan tetapi, seiring meningkatnya kesadaran publik dan peringatan otoritas kesehatan, para pemuka agama mulai menemukan titik temu dalam menghadapi virus mematikan ini. Pergeseran ini dapat kita temukan dalam sikap beberapa pemuka agama. Misalkan, pada kasus viralnya pernyataan UAS bahwa korona adalah tentara Allah, UAS memberikan klarifikasi dengan video yang diunggah Media Taqwa yang menyatakan bahwa pernyataan korona adalah tentara Allah tidak hanya datang dari dirinya sendiri, namun juga pernyataan dari para syaikh dan ahli agama di Timur Tengah. Perubahan sikap UAS juga terjadi setelah adanya himbauan pemerintah untuk melakukan jaga jarak, UAS segera memindahkan kajiannya menjadi daring.

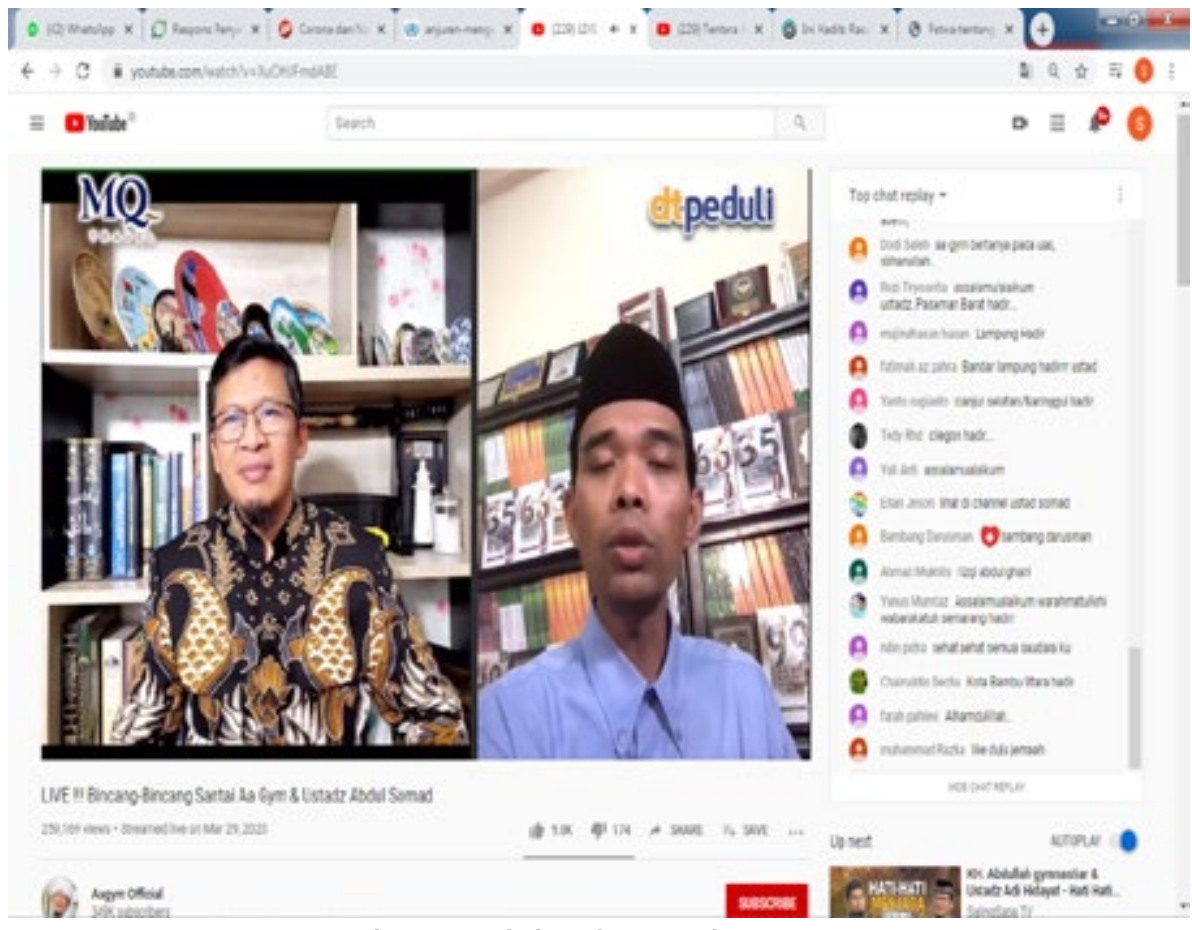

Gambar 1. Diskusi UAS dan Aa Gym

Sumber: https://www.youtube.com/watch?v=XuOHJFmdABE

Peran positif para pemuka agama dalam melakukan mitigasi Covid-19 dilakukan dengan memindahkan kajian terbuka menjadi kajian daring dan melakukan edukasi serta menggalang bantuan untuk tenaga medis dan masyarakat terdampak Covid-19. 
Aa Gym menunjukkan dirinya sebagai salah satu pemuka agama yang paling sigap merespons pandemi korona. Aa Gym tergolong aktif dalam membagikan himbauan terkait Covid-19 melalui kanal Youtube dan Instagramnya. Aa Gym melakukan sosialisasi langkah-langkah agar tidak tertular Covid-19 dengan bersepeda di lingkungan masyarakat. Melalui media sosialnya, Aa Gym juga memberikan contoh bagaimana mengadakan rapat ketika masa pandemi yakni dengan melakukan penjarakan fisik 1-2 meter sebelum pemberlakuan kebijakan bekerja dari rumah. Selain memberikan sosialisasi, Aa Gym juga menyalurkan bantuan sembako kepada masyarakat yang membutuhkan seperti difabel dan dhuafa, serta pemberian APD untuk tenaga kesehatan.

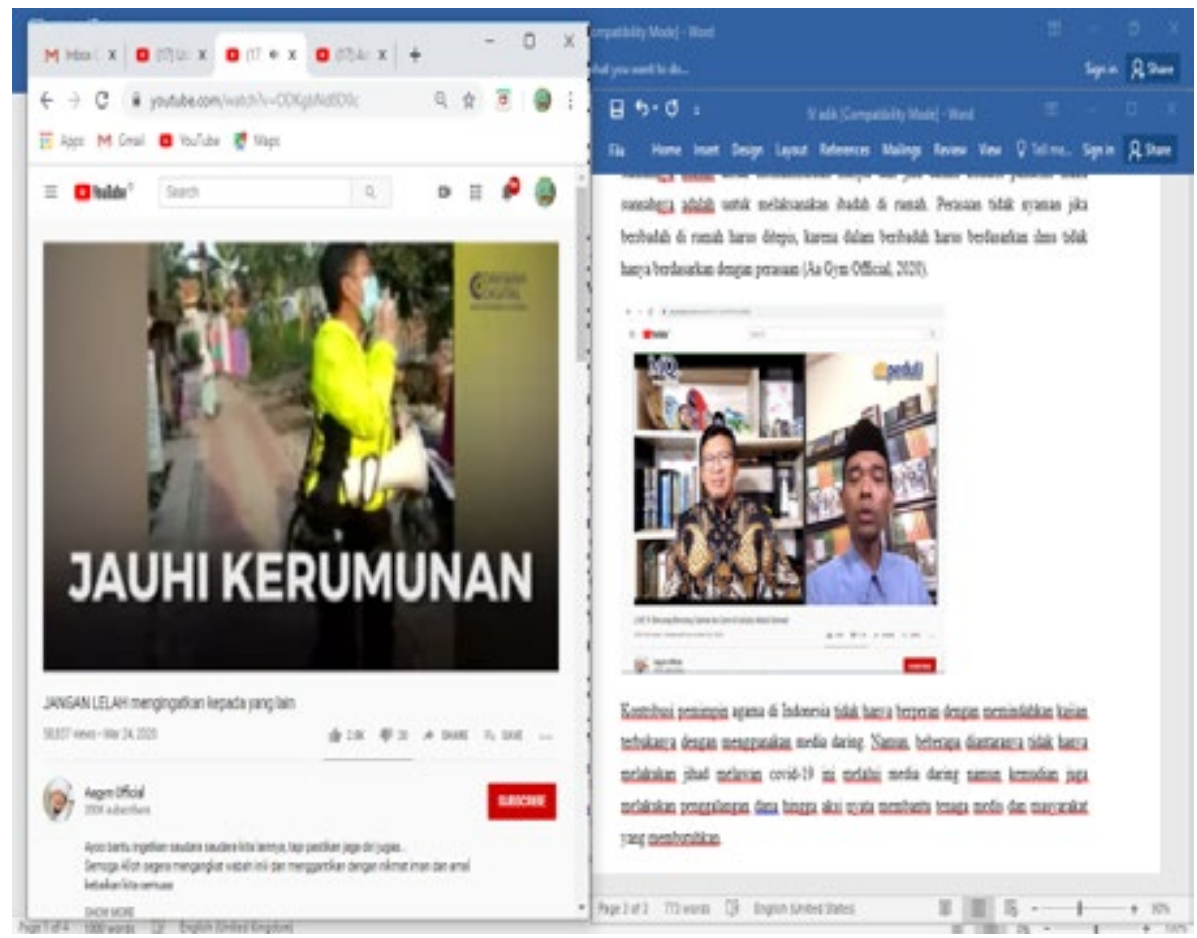

Gambar 2. Aa Gym memberikan sosialisasi kepada masyarakat

Sumber: https://www.youtube.com/watch?v=ODKgbNd8D0c.

Sikap pro-aktif juga dilakukan oleh UAH yang membentuk program khusus AMIN (Anshor-Muhajirin). Program ini bertujuan untuk mengatasi persoalan sosial-ekonomi di masyarakat yang timbul karena dampak dari wabah. Program ini terinspirasi dari Nabi Muhammad yang mempersaudarakan kaum Muhajirin Makkah yang saat itu mengalami kesulitan ketika berhijrah, dengan kaum Anshar Madinah yang secara ekonomi lebih berkecukupan. Program khusus ini meliputi pembagian masker, pembagian APD untuk tenaga kesehatan, 
pembagian sembako, pengadaan bilik disinfektan yang semuanya untuk umum serta program khusus yakni paket hafalan Qur'an bagi Muslim saattinggal di rumah (Adi Hidayat Official, 17/04/2020).

'Jihad' UAH melawan Covid-19 juga dilakukan melalui kanal youtubenya. Melalui kanal Youtube Adi Hidayat Official, UAH menyosialisasikan fatwa MUI mengenai kiat-kiat ibadah di rumah dan pedoman pengurusan jenazah pasien positif Covid-19, serta Fiqh Sholat ketika terjadi wabah. Pembahasan terkait dengan Covid-19, UAH secara khusus membahas dalam empat video terpisah yang berjudul 'UAH Berbicara Tentang Corona'. Video-video tersebut membahas bahwa korona merupakan ujian yang harus dihadapi dengan sabar. Sabar bukan sekadar menerima dengan pasrah namun diiringi dengan ikhtiar untuk mengatasi ujian dan menyerahkan seluruh hasilnya kepada Allah.

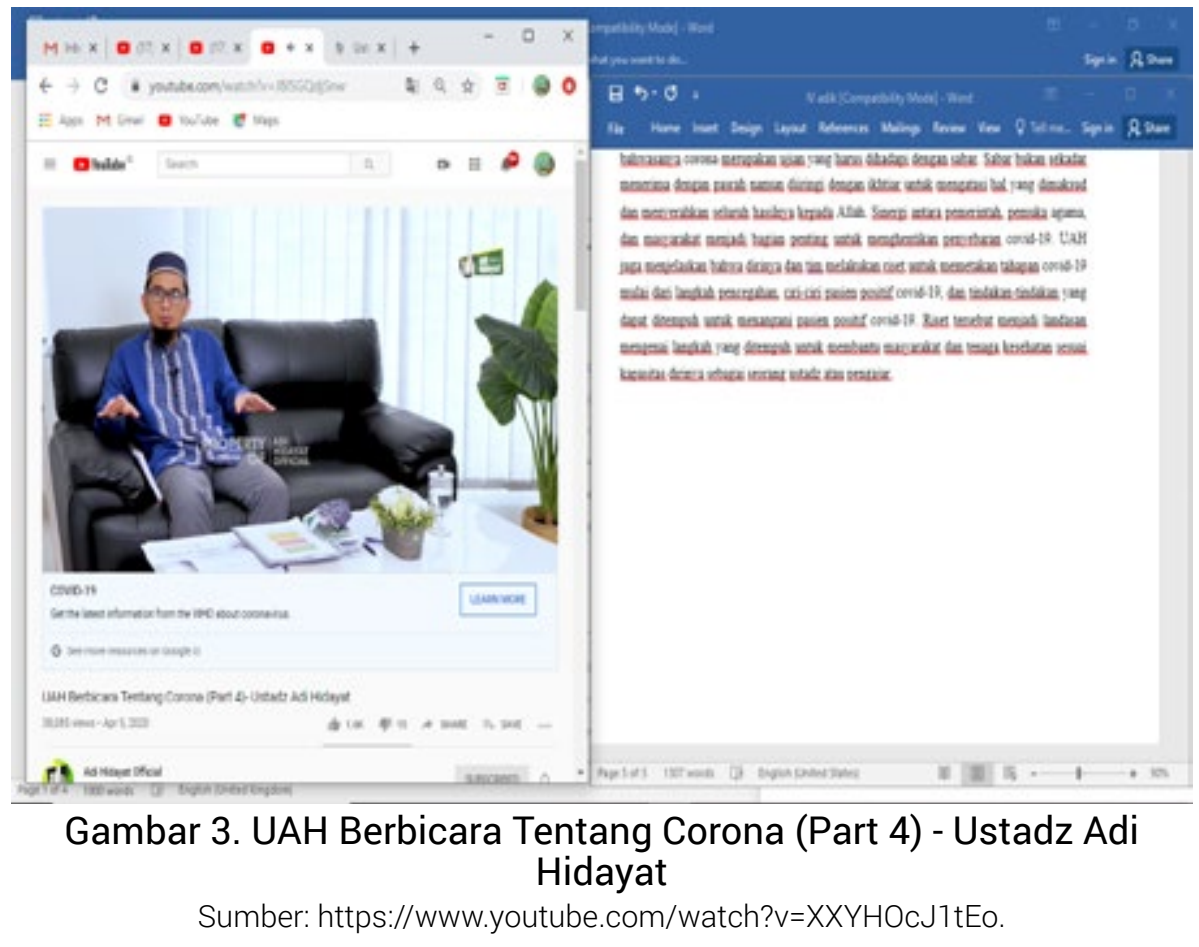

Kecanggihan teknologi komunikasi memudahkan masyarakat untuk mengakses informasi, hal ini disadari oleh para 'ustad selebriti' yang sangat akif menggunakan media sosialnya dalam berkomunikasi dengan jamaahnya. Dengan jumlah pelanggan (subscriber) yang mencapai jutaan, pesan dan himbauan-himbauan mereka dalam mengedukasi umat memiliki daya resonansi yang tinggi. Sebagai catatan tertanggal 28 April 2020, Aa Gym memiliki 352.000 pelanggan, sementara UAS dan UAH masing-masing memiliki 748.000 dan 
694.000 pelanggan di kanal Youtube mereka masing-masing. Sedangkan jumlah pengikut followers akun Instagram masing-masing, Aa Gym memiliki 5.5 juta, UAH memiliki 2.7 juta, dan UAS 3.1 juta pengikut.

Upaya merespons situasi pandemi secara responsif juga dilakukan oleh ormasormas keagamaan. Muhammadiyah melalui Tim MCCC-nya telah menyediakan 64 Rumah Sakit Muhammadiyah dan Aisyiyah untuk penanganan pasien korona. Terkait dengan pengurangan dampak Covid-19 secara sosial dan ekonomi, organisasi otonom Muhammadiyah dari pusat hingga daerah juga terlibat dengan pembagian sembako untuk masyarakat yang tergolong dhuafa di berbagai wilayah di Indonesia. Beberapa perguruan tinggi Muhammadiyah juga memberikan bantuan dalam bentuk sembako untuk mahasiswa yang memilih untuk tidak kembali ke rumah karena khawatir tertular atau menulari virus (TvMu, 25 April 2020).

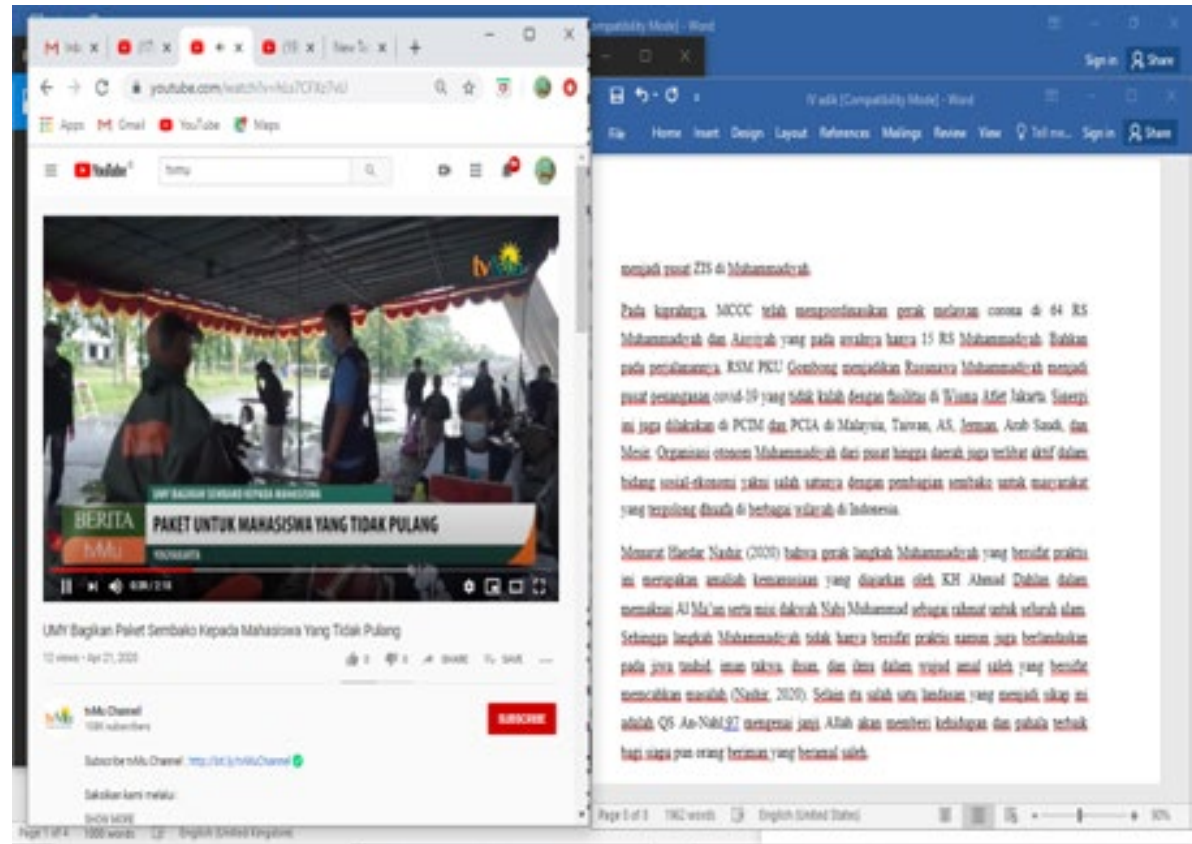

\section{Gambar 4. UMY Bagikan Paket Sembako kepada Mahasiswa yang Tidak Pulang \\ Sumber: https://www.youtube.com/watch?v=hLs7CFXz7vU}

Menurut Haedar Nashir (Republika, 17/4/2020), gerak langkah Muhammadiyah yang bersifat praktis ini merupakan amaliah kemanusiaan yang diajarkan oleh KH Ahmad Dahlan dalam memaknai Al Ma'un serta misi dakwah Nabi Muhammad sebagai rahmat untuk seluruh alam. Sebagai sarana edukasi publik, Muhammadiyah menggunakan kanal medianya berupa 'TVMu' dan 
'Muhammadiyah Channel' yang memberikan informasi terkini yang terjadi di masyarakat. Melalui laman covid19.muhammadiyah.id, Muhammadiyah juga memberikan layanan konsultasi agama selama wabah atau dapat langsung menghubungi Majlis Tarjih Muhammadiyah. Sedangkan terkait dengan fatwafatwa tata cara beribadah di tengah pandemi dari Muhammadiyah dapat diakses di situs pwmu.co.

Inisiatif-inisiatif mencegah dan menangani korona juga dilakukan oleh NU. NU membentuk satuan petugas yang khusus menangani isu Covid-19. Melalui NUcare, NU juga memberikan bantuan berupa masker di berbagai wilayah di Indonesia dan luar negeri. Terkait dengan banyaknya informasi hoax seputar korona, NU melalui Himpunan Pengusaha Nahdliyin (HPN) mengembangkan fitur Covid-19 dalam aplikasi GreenPages. Fitur ini memberikan informasi mengenai perkembangan terkini terkait dengan covid-19 dengan penyajian visual yang menarik (Ahmad, nu.or.id, 31 Maret, 2020). Pada masa pandemi, NU aktif menggelar 'Ngaji Online Kitab', Istighotsah dan Doa Bersama, kajian dari pemuka agama di NU secara daring melalui kanal Youtubenya sebagai upaya mendukung himbauan pemerintah dan fatwa MUI untuk beribadah di rumah dan menghindari kerumunan. NU juga mengerahkan para penjahit di berbagai daerah untuk memproduksi masker untuk kemudian dibagikan secara gratis (Yossihara, kompas.id, 19 April 2020).

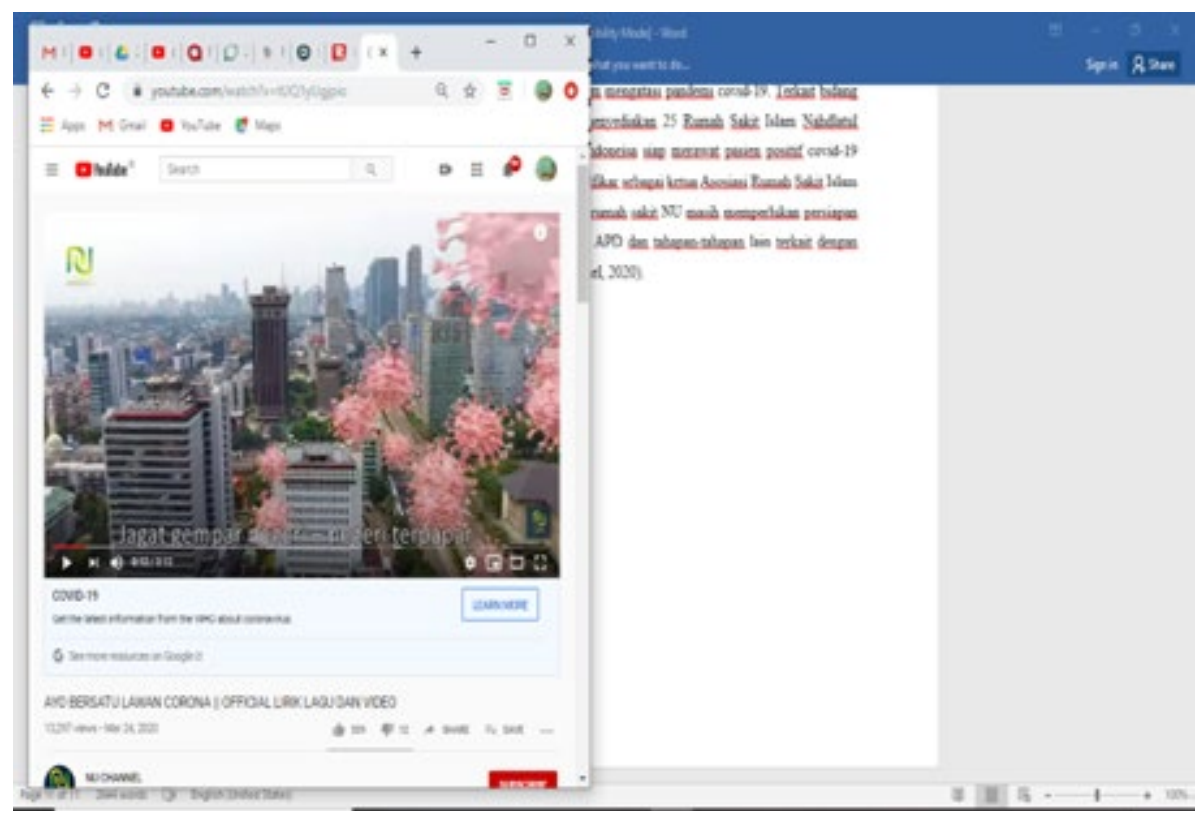

Gambar 5. Video official lagu Bersatu Lawan Corona

Sumber: https://www.youtube.com/watch?v=tUQ1yUgjpio. 
Berbeda dengan Muhammadiyah dan NU yang merupakan dua organisasi massa Islam yang memiliki jamaah yang besar, MUI sebagai wadah para ulama Indonesia memiliki peranan penting untuk mengeluarkan fatwa. Fatwa dari MUI menjadi salah satu rujukan penting bagi masyarakat Muslim di Indonesia. Setidaknya ada tiga fatwa yang dikeluarkan oleh MUI terkait dengan tata cara ibadah di masa pandemi, pertama, Fatwa No 14 tahun 2020 mengenai 'Penyelenggaraan Ibadah dalam Situasi Terjadi Wabah Covid-19'; kedua, Fatwa No 17 tahun 2020 tentang 'Pedoman Kaifiat Shalat bagi Tenaga Kesehatan yang Memakai APD saat Merawat dan Menangani Pasien Covid-19'; ketiga, Fatwa No 18 tahun 2020 terkait dengan 'Pedoman Pengurusan Jenazah (Tajhiz AlJana'iz) Muslim yang Terinfeksi Covid-19'. Selain mengeluarkan fatwa, MUI juga membentuk Satgas Covid-19 yang bertugas pada dua hal yakni edukasi dan sosialisasi tentang Covid-19 kepada masyarakat dan mengumpulkan serta mendistribusikan bantuan kepada petugas medis dan masyarakat yang terkena imbas Covid-19.

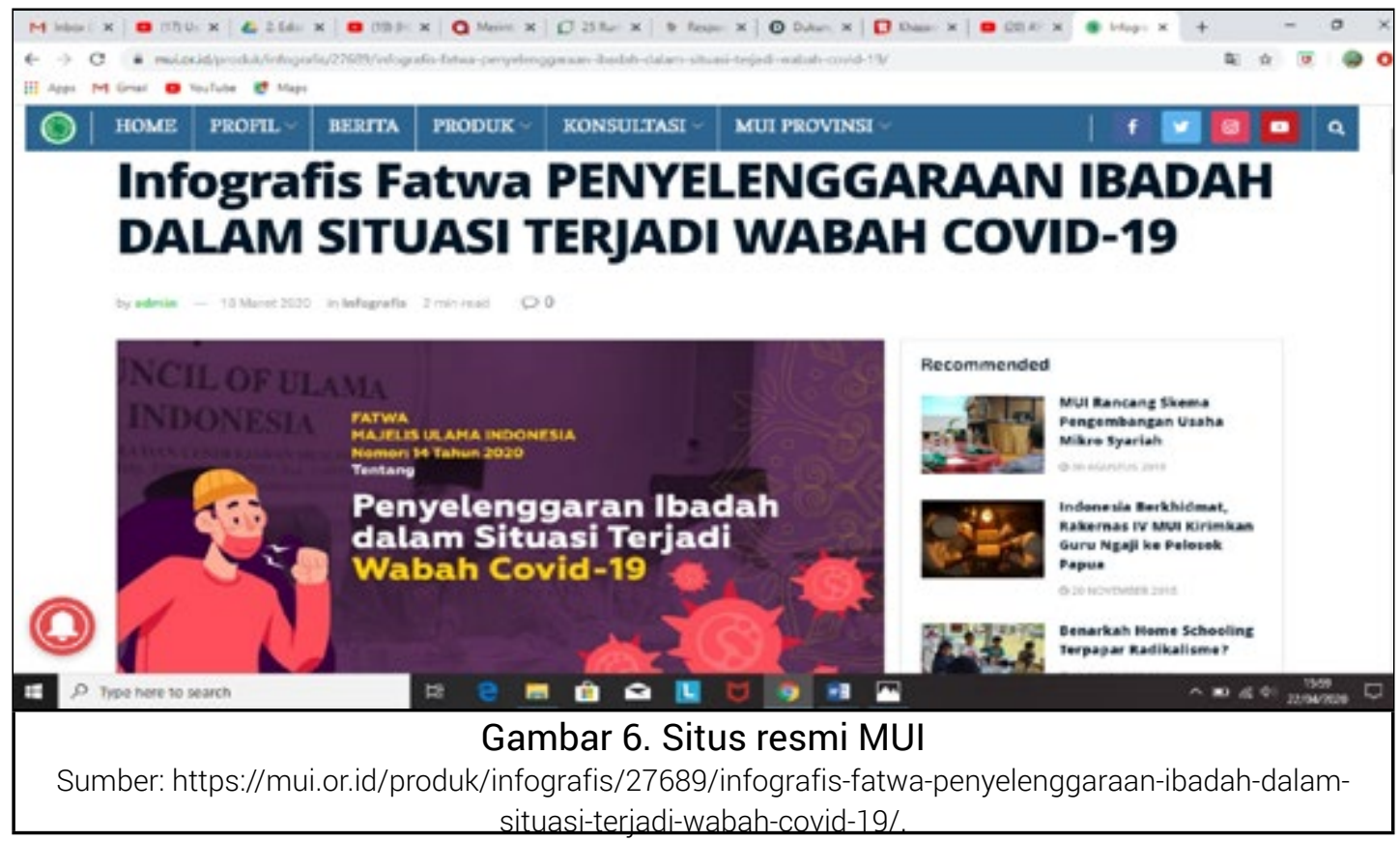

Perihal edukasi kepada publik, Satgas Covid-19 MUI melakukan beberapa program diantaranya adalah dengan penyebaran fatwa terkait Covid-19 melalui video, infografis, pencerahan tentang beribadah di bulan Ramadhan 
selama Covid-19, serta menyebarluaskan panduan dan penjelasan yang telah diterbitkan MUI Pusat tentang Covid-19.

Konvergensi otoritas agama dalam memitigasi situasi pandemi juga terlihat dalam upaya mereka melawan stigmatisasi dan ekslusi atas tenaga medis dan pasien positif korona. Stigmatisasi yang dilakukan oleh sekelompok masyarakat terlihat ketika terjadi penolakan jenazah positif korona dan pengusiran terhadap tenaga medis yang menangani pasien korona di sejumlah daerah. Penolakan jenazah positif korona di berbagai wilayah terjadi karena masyarakat khawatir terjadi penularan di lingkungan sekitar. Tidak hanya itu, di sejumlah daerah, tenaga medis yang menangani pasien korona justru harus terusir dari kontrakannya karena warga menolaknya. Menyikapi hal ini, para ustadz dan organisasi Islam menegaskan bahwa mereka yang meninggal karena wabah adalah syahid dan meminta masyarakat untuk tidak menolak pasien positif Covid-19. Misalkan, UAH melalui salah satu video di akun Instagramnya secara tegas meminta masyarakat untuk tidak menolak jenazah pasien positif covid-19. UAH menekankan bahwa seorang Muslim yang beriman tidak akan menolak jenazah khususnya pasien positif Covid-19 yang beriman Muslim karena berdasarkan hadist Rasullullah menyatakan bahwa seseorang yang meninggal karena wabah termasuk dari golongan syahid di akhirat. Aa Gym juga menghimbau agar masyarakat dalam menyikapi jenazah Covid-19 tidak kehilangan akhlak yang mulia. UAS menerangkan melalui kanal Talk Show Tv One (03/04) untuk menyerahkan kepada ahli kesehatan dan dari bidang kesehatan menyatakan bahwa jika pemakaman sudah sesuai dengan prosedur kesehatan maka virus tersebut tidak akan menyebar.

Ketua Umum PP Muhammadiyah, Haedar Nashir juga menghimbau agar masyarakat tidak bersikap berlebihan dengan menolak jenazah positif Covid-19, mereka adalah saudara kita sehingga masyarakat seyogyanya menunjukkan rasa empati dengan tidak menolak jenazah mereka terutama jika sudah sesuai dengan prosedur kesehatan (BeritaSatu, 20 April 2020). Ketua Satuan Tugas NU Peduli Covid-19, Muhammad Makky Zamzami juga meminta masyarakat berempati dan menerima jenazah untuk dimakamkan di lingkungan yang sudah dipilih (20.detik.com, 20 April 2020). MUI juga mengeluarkan fatwa terkait dengan tata cara pemakaman jenazah positif Covid-19 selain menyesuaikan dengan prosedur kesehatan juga mengikuti tata cara Islam.

Melalui narasi yang disajikan di atas, artikel ini menemukan bahwa dalam merespons situasi pandemi akibat penyebaran virus korona otoritas keagamaan 
Islam di Indonesia mengalami pluralisasi, fragmentasi, dan berujung pada konvergensi artikulasi wacana dan praksis keagamaan. Pada mulanya, otoritas agama baik otoritas agama baru yang direpresentasikan oleh 'ustad selebritis' maupun otoritas agama lama yakni 'ulama tradisional' dan organisasi masyarakat Islam arus utama seperti MUI, Muhammadiyah, dan NU mengalami pertentangan, polemik, hingga kontroversi dalam menyikapi Covid-19. Sikap cenderung meremehkan, mengingkari (denial), dan mengabaikan himbauan otoritas kesehatan masih mewarnai sebagian artikulasi wacana dan sikap otoritas keagamaan. Namun, perlahan seiring dengan meningkatnya kesadaran publik, peringatan dari otoritas kesehatan, dan arus informasi yang semakin kuat, otoritas agama mulai mengalami konvergensi dengan bersama-sama melakukan rangkaian upaya untuk memitigasi pandemi.

Konvergensi otoritas keagamaan dalam merespons pandemi terjadi baik di ranah diskursif maupun praksis. Di ranah diskursif, para pemuka dan organisasi keagamaan melakukan edukasi dan sosialisasi kepada publik khususnya umat Islam agar mematuhi regulasi dan himbauan otoritas kesehatan tentang pencegahan dan penanganan Covid-19. Mereka bekerja keras untuk meyakinkan umat Islam agar memperhatikan protokol kesehatan, menjaga gaya hidup sehat, tetap tinggal di rumah, dan yang paling utama mengeluarkan fatwa dan panduan ibadah di rumah masing-masing di saat pandemi. Mereka juga ramai-ramai melawan upaya stigmatisasi dan eksulusi sosial yang dilakukan oleh sebagian masyarakat terhadap pasien dan tenaga medis yang terjangkit korona. Dalam hal ini, mereka berupaya membangun jembatan pemahaman antara perintah agama dengan perintah otoritas kesehatan. Sementara itu, di ranah praksis, baik 'ustad selebritis' seperti UAH, UAS, dan Aa Gym maupun Muhammadiyah, NU, dan MUI berperan aktif dalam menggalang aksi solidaritas kemanusiaan untuk membantu tenaga medis dan untuk mengurangi kesulitan sosialekonomi warga yang terdampak situasi pandemi. Melalui aktivitas filantropi dan humanitarian, otoritas keagamaan berupaya menerjemahkan pesan Islam tentang kemanusiaan dan kepedulian sosial untuk merespons situasi pandemi. 


\section{Daftar Pustaka}

\section{Buku \& Jurnal}

Anderson, Jon W. 2003. “The Internet and Islam's New Interpreters.” In New Media in the Muslim World: The Emerging Public Sphere, edited by Dale F. Eickelman and Jon W. Anderson. Bloomington: Indiana University Press.

Akmaliah, Wahyudi. 2019. Politik Sirkulasi Budaya Pop: Media Baru, Pelintiran Agama, Dan Pergeseran Otoritas. Yogyakarta: Buku Mojok.

Arifianto, Alexander R. 2019. "Rising Islamism and the Struggle for Islamic Authority in Post-Reformasi Indonesia.” TRaNS: Trans-Regional-National Studies of Southeast Asia, 14-1.

Azra, Azyumardi, Kees Van Dijk, and Nico J.G. Kaptein. 2010. "Introduction.” In Varieties of Religious Authority: Changes and Challenges in 20th Century Indonesian Islam, edited by Azyumardi Azra, Kees Van Dijk, and Nico J.G. Kaptein, 211. Singapore: ISEAS Publishing.

Burhani, Ahmad Najib. 2016. "Aksi Bela Islam: Konservatisme Dan Fragmentasi Otoritas Keagamaan.” Jurnal Maarif Institute II (2).

Burhani, Najib. 2018. "Plural Islam and the Contestation of Religious Authority in Indonesia." In Islam in Southeast Asia: Negotiating Modernity, edited by Noorshahril Saat, 63-140. Singapore: Institut of Southeast Asia Studies (ISEAS).

Burhanuddin, Jajat. 2010. "Traditional Islam and Modernity: Some Notes on the Changing Role of the Ulama in Early Twentieth Indonesia." In Varieties of Religious Authority: Changes and Challenges in 20th Century Indonesian Islam, edited by Azyumardi Azra, Kees Van Dijk, and Nico J.G. Kaptein, 211. Singapore: ISEAS Publishing.

Iqbal, A. M. 2014. "Internet, Identity and Islamic Movements: The Case of Salafism In Indonesia." Islamika Indonesiana 105-84 (1) 1.

Muzakki, Akh. 2012. "Islamic Televangelism in Changing Indonesia: Transmission, Authority, and the Politics of Ideas." In Global and Local Televangelism, 63-45. London: Palgrave MacMillan.

Nashir, Haedar. 17 April 2020. Kiprah Muhammadiyah. Republika. Hal 7.

Slama, Martin. 2018. "Practising Islam through Social Media in Indonesia." Indonesia and the Malay World 4-1:(134) 46.

\section{Internet}

20.detik.com. 04 April 2020. NU: Korban Corona Mati Syahid, Jenazah Jangan Ditolak!. Diakses pada 20 April 2020 dari https://20.detik.com/ detikflash/200404055-20200404/nu-korban-corona-mati-syahidjenazah-jangan-ditolak. 
Aa gym. 14 Maret 2020. Daarut Tauhiid Menghentikan Sementara Kegiatan Belajar Mengajar. Diakses pada tanggal 01 April 2020 dari https://www.youtube. $\mathrm{com} /$ watch?v=qZgsQve2QfI\& $\mathrm{t}=158 \mathrm{~s}$.

Adi Hidayat Official. 13 April 2020. Program AMIN (Anshor-Muhajirin), Mengatasi Kendala Sosial Masyarakat -Ustadz Adi Hidayat. Diakses pada 17 April 2020 dari https://www.youtube.com/watch?v=KEsLLnlYK9w.

Adi Hidayat Official. 3 April 2020. UAH Berbicara Tentang Corona (Part 4-1) -Ustadz Adi Hidayat. Diakses pada 05 April 2020 dari https://www. youtube.com/watch? $\mathrm{v}=\mathrm{XXYHOcJ1tEo}$

Adiprasetio, Justito. 23 Maret 2020. Covid19-: Saat Ini Kita Membutuhkan Paranoia, Lebih dari Kapanpun. Diakses pada 01 April 2020 dari http:// remotivi.or.id/amatan/578/saat-ini-kita-membutuhkan-paranoia-lebihdari-kapanpun.

Ahmad, Fathoni. 31 Maret 2020. HPN Kembangkan Informasi Valid tentang Covid19. Lewat Aplikasi Greenpages. Diakses pada 01 April 2020 dari https://www.nu.or.id/post/read/118516/hpn-kembangkan-informasivalid-tentang-covid-19-lewat-aplikasi-greenpages.

Albanna, Morteza Syariati. 03 Maret 2020. MUI Bela Ustaz Abdul Somad soal Corona Tentara Allah. Diakses pada tanggal 01 April 2020 dari https:// www.tagar.id/mui-bela-ustaz-abdul-somad-soal-corona-tentara-allah.

Arigi, Fikri. 6 Maret 2020. PP Muhammadiyah Bentuk Tim Covid19- Command Center. Diakses pada 01 April 2020 dari https://nasional.tempo.co/ read/1316289/pp-muhammadiyah-bentuk-tim-covid-19-commandcenter.

Azra, Azyumardi. 2020. Virus Corona, Splinter Agama. Diakses pada tanggal 17 April 2020 dari https://republika.co.id/berita/q7s4i4282/virus-coronasplinter-agama1-.

Basuki, Novi. 2020. Surat Terbuka untuk Ustad Abdul Somad yang Sebut Corona Adalah 'Tentara Allah'. Diakses pada 01 April 2020 dari https://mojok. $\mathrm{co} / \mathrm{nvb} / \mathrm{esai} /$ surat-terbuka-untuk-ustaz-abdul-somad-yang-sebut-coronaadalah-tentara-allah/.

BeritaSatu. 3 April 2020. Muhammadiyah: Jangan Tolak Jenazah Pasien Corona. Diakses pada 20 April 2020 dari https://www.youtube.com/ watch?v=ybHMI $1 \mathrm{qhz} 3 \mathrm{Q}$.

CNN Indonesia. 11 April 2020. Aa Gym Imbau Warga Tidak Menolak Jenazah Covid19-. Diakses pada 20 April 2020 dari https://www.youtube.com/ watch? $=-\mathrm{kOKBaMiElO}$.

Fathurahman, Oman. 2020. Corona dan Narasi Agama. Diakses pada 17 April 2020 dari https://indopolitika.com/corona-dan-narasi-agama/.

Hosen, Nadirsyah. 29 April 2020. When religion meets Covid19-in Indonesia: more than a matter of conservatives and moderates. Diakses pada 29 April 2020 
dari https://indonesiaatmelbourne.unimelb.edu.au/when-religionmeets-covid-19-in-indonesia-more-than-a-matter-of-conservatives-andmoderates/

KompasTV. 2020. Indonesia Terhindar dari Corona, Ma'ruf Amin: Berkat Ulama Selalu Baca Qunut. Diakses pada tanggal 01 April 2020 dari https://www. youtube.com/watch?v=Oc7GTpNPN5M.

Media Taqwa. 28 Maret 2020. Tentara Allah bernama Corona. Diakses pada 01 April 2020 dari https://www.youtube.com/watch?v=GG-b715Em9w

MUI. 17 Maret 2020. Fatwa No 14 Tahun 2020 - Penyelenggaraan Ibadah Dalam Situasi Terjadi Wabah Covid19. Diakses pada 02 April 2020 dari https:// mui.or.id/berita/27674/fatwa-penyelenggaraan-ibadah-dalam-situasiterjadi-wabah-covid19-\%.

MUI. 2020. Infografis Fatwa Penyelenggaraan Ibadah dalam situasi terjadi Wabah Covid19. Diakses pada 27 April 2020 dari https://mui.or.id/produk/ infografis/27689/infografis-fatwa-penyelenggaraan-ibadah-dalam-situasiterjadi-wabah-covid 19-/.

MUI. 28 Maret 2020. Fatwa No 17 Tahun 2020 - Pedoman Kaifiat Shalat Bagi Tenaga Kesehatan yang Memakai Alat Pelindung Diri (APD) Saat Merawat dan Menangani Pasien Covid19. Diakses pada 02 April 2020 dari https://mui. or.id/produk/fatwa/27748/fatwa-no-17-tahun-2020-pedoman-kaifiatshalat-bagi-tenaga-kesehatan-yang-memakai-alat-pelindung-diri-apd-saatmerawat-dan-menangani-pasien-covid 19\%.

MUI. 28 Maret 2020. Fatwa No 18 Tahun 2020 -Pedoman Pengurusan Jenazah (Tajhiz Al-Jana'iz) Muslim yang Terinfeksi Covid19. Diakses pada 02 April 2020 dari https://www.nu.or.id/post/read/119151/anggap-nu-hanyaormas-keagamaan--seorang-wartawan--kenapa-ikut-tangani-covid-19-.

MUI. 3 Maret 2020. Tausyiah Dewan Pimpinan MUI Menangkal dan Menghadapi Penyebaran Virus Corona. Diakses pada 01 April 2020 dari https://mui. or.id/press-release/27636/tausiyah-dewan-pimpinan-majelis-ulamaindonesia-menangkal-dan-menghadapi-penyebaran-virus-corona/.

NU Channel. 23 Maret 2020. Habib Luthfi Bin Yahya: Jangan Terlalu Takut Corona!! Takutlah Allah Swt!!. Diakses pada tanggal 01 April 2020 dari https://www.youtube.com/watch?v=MQjO8qMfkpk.

NU Channel. 24 Maret 2020. Ayo Bersatu Lawan Corona || Official Lirik Lagu dan Video. Diakses pada 20 April 2020 dari https://www.youtube.com/ watch? $=$ tUQ1yUgjpio.

PUSAD Paramadina. 2020. Agama di Era Corona. Diakses pada 21 April 2020 dari https://www.youtube.com/watch? $=$ =mBVOPJcxpk.

Sahal, Husni. 3 Maret 2020. Prihatin atas Tersebarnya Virus Corona, PBNU Instruksikan Nahdliyin Baca Qunut Nazilah. Diakses pada 04 April 2020 dari https://www.nu.or.id/post/read/117434/prihatin-atas-tersebarnyavirus-corona--pbnu-instruksikan-nahdliyin-baca-qunut-nazilah. 
Shihab, Najwa. 22 Maret 2020. Benarkah Corona Tentara Allah? | Shihab \& Shihab. Diakses pada tanggal 01 April 2020 dari https://www.youtube. com/watch?v=gtd4xR_YjY4.

Talk Show tvOne. 3 April 2020. Ustadz Abdul Somad Tanggapi Penolakan Jenazah Pasien Corona. Diakses pada 20 April 2020 dari https://www.youtube. $\mathrm{com} /$ watch? $=$ pedToxAlM5g.

TvMu Channel. 21 April 2020. UMY Bagikan Paket Sembako kepada Mahasiswa yang Tidak Pulang. Diakses pada 25 April 2020 dari https://www.youtube. $\mathrm{com} /$ watch? $=\mathrm{hLs} 7 \mathrm{CFXz} 7 \mathrm{vU}$.

Ustadz Abdul Somad Lovers. 9 Februari 2020. Himpunan Daie Ummah Nusantara. Diakses pada tanggal 01 April 2020 dari https://www.youtube.com/ watch? $=-$ pxzAn_ywDc\&t $=60$ s.

Watchdoc Documentary. 2020. Agama dan Wabah Penyakit. Diakses pada 17 April 2020 dari https://www.youtube.com/watch?v=JJRKASvqYzo.

Wicaksono, Pribadi. 9 April 2020. Jejak Peserta Ijtima Gowa yang Meninggal Karena Corona ditelusuri. Diakses pada 27 April 2020 dari https:// nasional.tempo.co/read/1329508/jejak-peserta-ijtima-gowa-yangmeninggal-karena-corona-ditelusuri.

Yossihara, Anita. 19 April 2020. Cahaya di Tengah Kabut Covid19-. Diakses pada 22 April 2020 dari https://kompas.id//baca/polhuk/19/04/2020/ cahaya-di-tengah-kabut-covid19-/. 